\author{
Margarita María Ayala Doval \\ MA in Educational Technology \\ Tecnologico de Monterrey, Monterrey, México \\ ORCID ID 0000-0003-3015-4329 \\ margaritamariaayala@hotmail.com \\ Marcela Georgina Gómez-Zermeño \\ Professor, $\mathrm{PhD}$ in Educational Innovation \\ Tecnologico de Monterrey, Monterrey, México \\ ORCID ID 0000-0002-5427-2891 \\ marcela.gomez@itesm.mx
}

\title{
SELECTION AND QUALITY OF LEARNING OBJECTS. ARE THEY USABLE AND REUSABLE?
}

\begin{abstract}
This pilot- study focused on the evaluation of Learning Objects for face-to-face and online education, proposing a set of quality indicators for design teams to consider while selecting learning material. The aim was to find out whether the Learning Objects were suitable enough to be used and/or reused. A sample of teachers, tutors and computer technicians of a graduate program in a Colombian university participated in the study. To analyze the data collected, indicators for the evaluation of the quality of Learning Objects were based on three main aspects: the role of the tutor and their previous experience, the design process, and the evaluation of the learning object. Conclusions established that a standardization of Learning Objects may be difficult, however, in order to be usable and reusable, these Learning Objects must all be flexible to adapt to students' needs.
\end{abstract}

Keywords: Learning Objects; repositories; information and communication technologies; indicators, quality.

\section{INTRODUCTION}

New educational theories have been influenced by society's transformation and demands, such as immediacy, accessibility, coverage, and mobility of information. In past times, the main tendency was classroom education; today, there are different models of teaching, among which we can find blended and online models. The teaching-learning processes in educational institutions are constantly the subject of discussion. Innovation, research, and the use of Information and Communication Technologies (ICT) are transcendental aspects in the pedagogical processes; as well as the methodology employed by the teachers in the classrooms [1]. The development of digital libraries and repositories is the result of social, educational and technological changes and conditions [2]. Some public authorities in education acknowledge the lack of access to quality education and technology for the population as one of the causes for the lack of democratic educational spaces.

The current knowledge society is characterized by rapid growth and spread of information through ICT. Both teachers and students have access to large clusters of information in their educational environments. Over time, the role of the students has gradually been changing, becoming more participatory in the construction of their knowledge and discernment to contribute to the construction of various educational resources for individual and collaborative learning.

Online education occupies an increasingly important place in society due to the advances of ICT, as they offer new resources for teaching classes, and create the need to implement an instructional design based on technology. Online education includes various models that are based on constructivist and socio cultural approaches; this way, the students' role has transformed from a passive to an active function: from a recipient to a producer of knowledge. 
As a result, students can have access to resources that facilitate the learning construction and, in turn, promote the development of their autonomy. Regarding this aspect, now, the instructional design is interactive, seeks to encourage cooperative work, motivate and fully train the student [3].

Additionally, Learning Objects are the result of the creation of resources that enable a three-vectorial student interaction: information, technologies, and peers, teachers and partners. In this context, Learning Objects become crucial because they are the means by which the students interpret and assimilate knowledge. Therefore, adequate and relevant objects are expected for a better use[4].In fact, Learning Objects should be conceived bearing in mind students' context, which involves an interaction between contents and multimedia environments[5].

Currently, many educational institutions offer online courses and incorporate ICT into their environments to articulate contents, activities and educational resources, including Learning Objects (LO) [6]. LOsare an essential part of online courses design. However, there are many resources on the Internet that may be used in virtual platforms or as a resource in face-to-face classes, although they may fail to meet the desired learning objectives. For these reasons, it is important to consider the need to find effective indicators for the research, creation, and evaluation of LO.

The creation of precise models of Learning Objects will allow a more efficient reutilization, as it represents one of its main traits [7]; additionally, the development of interactive materials can also be used among institutions with different curricula [8].

Several pedagogical models have been designed to facilitate the integration of ICT resources in education. In particular, we highlight the work of Tomei [9], who presents a taxonomy of six levels of mastery of technology:

- Level 1. Understanding technology. Minimum degree of competence of the teacher and students of technology, computers, educational programs, office automation, Internet, and its effective implementation as a learning strategy.

- Level 2. Collaboration and exchange of ideas. Ability to use technology for effective interpersonal interaction.

- Level 3. Decision-making and problem solving. Ability to use technology in new and concrete measures to analyze, evaluate and judge situations.

- Level 4. Learning with technology. Identification, use and application of existing technology in unique learning situations.

- Level 5. Teaching with technology. Charting on technologies, combining different technologies for teaching materials.

- Level 6. "Tech-ology" study technology. Ability to judge the universal impact, shared values, and social implications of the use of technology and its influence on the teaching-learning process.

These levels offer a way forward to achieve higher levels of integration of technology for educational use.

Learning Objects can be defined as units of educational resources that comprise content and learning activities within specific contexts [10]. This concept of unity is complemented by saying that these Learning Objects are information units that can be adapted to different formats aimed at user interaction with content through digital media [11]. In other words, there is a "dialogue" between the user and teacher, where the learning object is the communicator channel.

The LO have six main elements: introduction, theoretical modules, objectives, activities, conclusions and evaluation. In their design, consideration must be given to users' 
acquiring competencies that allow cognitive and technological skills according to the context of the student [12].

The design of efficient Learning Objects requires considering a set of criteria that must be established according to their goals. Virtual Learning Objects must be reusable, flexible and adaptable to different contexts and applications [13]. The creation of this material requires a certain amount of time dedicated to its design and search for resources [10]. Among other characteristics, the object must possess interoperability, durability, and accessibility [13]. An LO can be interoperable if it is applicable to different technology platforms. In addition, the ideal is that other designers can easily operate the object. If this is not possible, time and the possibility of reusing it will be lost [13]. Durability is closely related to interoperability: it is to design learning units that can be used for a considerable period and prevent them from not being affected by technological advances [13]. In addition, it is expected that LOs do not have to be constantly reconfigured by evolutionary change of ICT [10]. Therefore, when choosing the content caution is advised, because although LOs must be contextualized, they should have a timeless quality to them. In fact, accessibility is ensuring that the learning object is always available, not just for a limited time period [13]. It is also an important to consider asynchronous LOs, both in virtual Learning Objects and in virtual education; it is important that the materials are available at all times.

If Learning Objects are going to be reusable, they need to be presented in a way that they are not monotonous or predictable. On the contrary, they should activate the memory, take the users' previous knowledge to build new one. It is further intended that these Learning Objects awaken the senses, being diverse, attractive and most importantly with understandable content [11].

Problem statement. Considering the literature review regarding the design and application of virtual Learning Objects, this research focused on the questions: How to select and evaluate Learning Objects that can be reusable and applied in virtual contexts? Which are the quality indicators for an efficient design of a learning object? Based on these questions, the purpose of this investigation is to propose a set of indicators to evaluate the quality of a learning object.

This research focused on the process of selecting resources that can be used in virtual learning environments, and their appropriateness for effective learning. This process can be difficult to carry out since the creation of LOmust meet the instructional design goals and address the students' needs. In the development and implementation of a curriculum, many internal and external factors affect the choice of learning resources, which is why teachers and instructional designers tend to use material that has not been adapted previously to their specific context.

Purpose of the article. This study addresses the need to identify the quality indicators that serve as a reference to assess and select Learning Objects. As a result, they could use those that meet the objectives of the instructional design and the needs of teachers and students. The study aimed to propose the guidelines for the design of evaluation instruments for the selection of quality Learning Objects, according to the students' learning needs and an adequate instructional design.

\section{METHODS}

The research was conducted with across-sectional, ex-post facto and exploratorydescriptive design. Accordingly, the data were collected at one specific point in time to examine how an independent variable, present prior to the study, affected a dependent variable, with the intent of learning about these variables, which are not well known beforehand. The quantitative method was chosen to make an exploration of the participants' 
current situation; that is, learning about the LO teachers use, to make a description and complement it with the collection of information through surveys. The purpose of this quantitative research is to reach objectivity as closely as possible and quantification of reliable data, which implies a constant verification of its validity [14].

This research was carried out in the Law Faculty of a Colombian private higher education institution, which in 2014 began offering online programs. The sample was composed of teachers from different disciplinary areas and functions in the institution. In the study, 20 teachers were invited to participate, including authors and online tutors on the Master in International Taxation and Foreign Trade programs and the online course in International Taxation. Also, we included the opinion of computer technicians from the IT department who work in the implementation of the online courses in the institution and are responsible for the use and maintenance of the Moodle 2.8educational platform, which is used for the course.

The selected sample was composed of professionals in charge of the design of the content and evaluation activities of the modules. The tutors accompany and assess students in the development of the activities, they are skilled professionals in their area; however, most of them had no training in pedagogy and their teaching experience was acquired through the years of practice. In addition, in the case of the online master, it was analyzed if the participants of the sample used Learning Objects efficiently in their work. In the particular case of the master program of this research everyone in the sample, tutors, instructional designers and the members of the IT department, were involved in the instructional design and the use of Learning Objects.

A survey and an interview were applied: first, the survey was designed in Google Forms in order to gather data and facilitate its collection. The instrument had 28 questions (25 openended and 3 closed-ended questions), divided into four categories: personal data, virtual learning platforms, Learning Objects design, and context and students. Afterward, structured interviews were conducted to the instructional designers, tutors and members of the IT department. The interview guide consisted of 17 questions of which 12 were multiple choice and five closed answers, in six categories: personal information, professional experience, experience in virtual courses as a student, concept of Learning Objects, implementation of Learning Objects, feedback of Learning Objects. Both instruments were specifically created for the research, with the intent of exploring the topic of LO understanding and use, and included indicators from previous research [3],[4], [6].

For the application of the instruments and data collection, electronic resources such as e-mail, digital formats surveys (Google Forms) and the communication software Skype for the interviews were used.

The research instruments intended to obtain information concerning the domain that participants have of online teaching platforms, technological tools, and LO, and how they are developed and evaluated by the designers, tutors, and students. For analysis of the information collected, we measured the frequency of occurrence of the variables [15].

\section{FINDINGS AND DISCUSSION}

After completing the data collection, we categorized the sample according to the following criteria: age, occupation and teaching experience. As for the age of the participants, $43 \%$ of the respondents were between $40-50$ years; $36 \%$ were 50 or older and the remaining $21 \%$ of the participants were aged between 20 and 40 .

From the 17 teachers who accepted the invitation to participate in the research, 14 participants responded, among them eight men and six women. Although gender was not one 
of the variables to consider in the analysis, the proximity of its distribution to the media facilitated the decision to dismiss it as a factor that could affect the results.

\subsection{Indicators of quality for Learning Objects}

The first step of the research analysis was choosing the indicators. It was necessary to establish their intention and criteria that would measure the quality standards to address the research questions. We considered what Ardila-Rodríguez [16] expressed about the ideal conditions for quality indicators in virtual learning environments that must provide: "the tools and procedures that apply to the design... and in turn theory for evaluating whether or not it meets the design and synthesize to standardize their quality" [16, p. 192].

In other words, the author stresses the importance of determining whether the LO, prior to their use, comply with the requirements of the course, its content, and students. Towards solving research questions, three categories of indicators were established. The first indicators (Table 1) sought to establish metrics regarding the skills, knowledge and use of the tools of a virtual platform for the development of reusable Learning Objects.

Table 1

\section{Indicators to assess the role of the tutor}

\begin{tabular}{|c|l|l|}
\hline \multicolumn{1}{|c|}{ Area of study } & \multicolumn{1}{|c|}{ Indicator } & \multicolumn{1}{c|}{ Function } \\
\hline \multirow{3}{*}{$\begin{array}{l}\text { The tutor (T) as a designer } \\
\text { of Learning Objects }\end{array}$} & $\begin{array}{l}\mathrm{IT}^{1} \text { : Tutor has previous } \\
\text { knowledge in virtual } \\
\text { environments. }\end{array}$ & $\begin{array}{l}\text { To evaluate if the tutor as a designer has } \\
\text { experienced a double role as a student } \\
\text { too. }\end{array}$ \\
$\begin{array}{l}\mathrm{IT}^{2} \text { : The tutor knows and uses } \\
\text { the tools of the platform } \\
\text { adequately }\end{array}$ & $\begin{array}{l}\text { The more tools they use, the more } \\
\text { knowledge of the platform they have and } \\
\text { the more they facilitate the student's } \\
\text { content appropriation. }\end{array}$ \\
\hline
\end{tabular}

The second group of indicators (Table 2), concerning the process of developing LO, intended to assess if the learning object meets the following criteria: prior planning, support of an interdisciplinary team, contextualization and support through a repository of LO. Based on these aspects, it was possible to find out whether resources and preparedness for the design of the LO, were aspects that tutors considered as relevant when starting the process of building them.

Table 2

Indicators for assessing the design process of Learning Objects in virtual environments

\begin{tabular}{|c|c|c|}
\hline Area of study & Indicator (I) & Function \\
\hline \multirow{4}{*}{$\begin{array}{l}\text { Design process }(\mathrm{D}) \text { of } \\
\text { Learning Objects }\end{array}$} & $\begin{array}{l}\mathrm{ID}^{1} \text { : Previous planning before } \\
\text { producing Learning Objects. }\end{array}$ & $\begin{array}{l}\text { The creation of a learning object involves an } \\
\text { inspection of the course and the parameters to } \\
\text { consider through a checklist. }\end{array}$ \\
\hline & $\begin{array}{l}\mathrm{ID}^{2}: \text { The learning object is } \\
\text { designed by an interdisciplinary } \\
\text { group of professionals. }\end{array}$ & $\begin{array}{l}\text { The elaboration process of Learning Objects } \\
\text { involves the participation of professionals from } \\
\text { different areas in pedagogy and information } \\
\text { technologies. }\end{array}$ \\
\hline & $\begin{array}{l}\mathrm{ID}^{3}: \text { It considers the socio- } \\
\text { cultural context and student's } \\
\text { profile. }\end{array}$ & $\begin{array}{l}\text { Designing Learning Objects requires analyzing } \\
\text { the target audience and the context of the } \\
\text { student. }\end{array}$ \\
\hline & $\begin{array}{l}\mathrm{ID}^{4}: \text { It has a repository of } \\
\text { Learning Objects. }\end{array}$ & $\begin{array}{l}\text { Creating a repository of Learning Objects } \\
\text { facilitates the instructional designer's goals } \\
\text { and it implies a rigorous process of elaboration } \\
\text { and planning. }\end{array}$ \\
\hline
\end{tabular}

The third set of indicators (Table 3) are based on the evaluation of the final product of the LO. The criteria sought to determine the follow-up process. 
Indicators for the Evaluation (E) of the Learning Object

\begin{tabular}{|l|l|l|}
\hline \multicolumn{1}{|c|}{ Area of study } & \multicolumn{1}{|c|}{ Indicator (I) } & \multicolumn{1}{c|}{ Function } \\
\hline $\begin{array}{l}\text { Evaluation (E) of the } \\
\text { Learning Object }\end{array}$ & $\begin{array}{l}\text { IE }{ }^{1} \text { Verification list of the } \\
\text { requirements in a Learning } \\
\text { Object. }\end{array}$ & $\begin{array}{l}\text { A verification list will allow a deeper } \\
\text { understanding of the elements that compose a } \\
\text { learning object. Likewise, it shows a series of } \\
\text { parameters to follow. }\end{array}$ \\
\cline { 2 - 3 } & $\begin{array}{l}\mathrm{IE}^{2}: \text { Pilot test and/or feedback of } \\
\text { the learning object. }\end{array}$ & $\begin{array}{l}\text { Peers and students support can improve and } \\
\text { help develop the quality of the learning } \\
\text { object. }\end{array}$ \\
\cline { 2 - 3 } & $\begin{array}{l}\mathrm{IE}^{3} \text { : The learning object fulfills } \\
\text { the goals of the course. }\end{array}$ & $\begin{array}{l}\text { The learning object must comply with the } \\
\text { course's objectives and there is consistency } \\
\text { with the contents. }\end{array}$ \\
\cline { 2 - 3 } & $\begin{array}{l}\text { IE } \text { the learning object considers } \\
\text { the students' needs. }\end{array}$ & $\begin{array}{l}\text { The learning object must be understandable } \\
\text { for the student to facilitate knowledge } \\
\text { acquisition. }\end{array}$ \\
\hline
\end{tabular}

The analysis of the data collected in both instruments was organized into three categories, as shown below.

\subsection{Category 1: Definition and use of LO in instructional design}

The questions inquired about participants' knowledge of learning platforms and tools. The majority, $57 \%$ of the respondents, knew most of the tools of the platform and $36 \%$ were familiar with some of them.

While interpreting these results according to the indicator $\mathrm{IT}^{2}$, it was observed that knowing the tools available for the tutor could contribute to a better selection and adaptation of the LO, which means its selection should be based on the context and needs of the instructional design of the course. Therefore, it was essential that the instructional designer should be familiar with their surroundings, in this case, a virtual learning platform. The development of skills in virtual learning environments is essential for the establishment of the key factors to be consistent with the objectives of instructional design [17].

Regarding LO repositories, nine participants responded that they had them, and one participant expressed the following:

"Yes, but it has very little meaning to use because the elements to consider in the design of each course and their activities must be varied to adapt to the new items that need to be considered. Moreover, we must not deny that the existence of such repositories induce to repeat strategies and objects, or do not correspond to the elements that would be necessary to incorporate".

Also, to achieve quality learning, it is necessary that LOs be updated and adapted to the user's needs[18]. Continuing with the analysis, we investigated about the aspects that are needed to determine the applicability and relevance of the LO, and most participants said they designed LO based on the role and objectives. This involves a knowledge of the students' skills, as the higher a skill, such as analysis, the LO can focus on more complex aspects.

With the indicator $\mathrm{IT}^{1}$, participants understood the difficulties that a student could face as a virtual user. Ten of the respondents commented that they had the opportunity to study in virtual learning environments, and their experience has been positive.

Referring to the analysis of the necessary aspects to determine the applicability and relevance of learning and whether Learning Objects are designed based on competencies (indicators 1 and 2) the answer was positive from most respondents, who acknowledged the importance of ICT skills to develop LOs. 
As for the software, $79 \%$ of participants mentioned they use the word processor Word to start the design process of LO and 64\% make this model without the support of an interdisciplinary team.

Regarding research about LO, seven respondents defined them in two concepts: content and activities. When comparing these elements to the definition of the Ministry of National Education of Colombia MEN [10], their similarity was noted as both involved contents and activities that would help students understand what they have learned and adapted it to their prior knowledge.

In addition, the intention of analyzing the LO design was to reflect quality standards that allow its reuse. By questioning the professors about their definition of LO, no absolute definitions were provided. This is consistent with the role of LO since these cannot be seen only as elements, but as resources that enable communication between student and tutor content through ICT [19].

Regarding the design of LO, $90 \%$ of participants stated that they used classroom activities and resources found on the Internet. Relating this information with the indicator ID4, the importance of tangible resources to build LO was evident.

\subsection{Categories 2 and 3: Evaluation criteria and quality standards}

In terms of evaluation criteria and quality standards, question 9 was about the key aspects of developing an LO (indicator 2). We found that the majority of respondents felt that aspects such as learning context, content, profile, and skills to develop in students were the most relevant. The mentioned above relates to the $\mathrm{ID}^{3} \mathrm{IE}^{4}$ indicators that measure student's needs within a context. Onrubia sums it up, "the implementation in real contexts of LO is a practical task which is a constant and continuous relationship between design and use" [19, p. $11]$.

The participants were asked about the use of checklists, and most said they agreed to utilize this kind of format to assess LO, corresponding to the parameters of $\mathrm{IE}^{1}$ indicator. Moreover, we sought to find if tutors used techniques to assess their LO, the most frequent response was the feedback given by students. We waited until the end of the process to check whether the LO was designed to be reusable or functional interoperable. Therefore, checkpoints of quality control were omitted during the instructional design [10].

Regarding the role of computers in school, this is not only limited to LO but also to serve as facilitators in the process of design and application of resources. The expected objective is fulfilled according to the $\mathrm{ID}^{2}$ (see Table 2) measuring interdisciplinary in the creation of the LO.As for the assessment criteria, it appears that these are not explicitly defined, but there is a checklist for evaluation.

The analysis concludes with the category related to quality. Sharing some recommendations, participant 3 said, "Firstly you must be a virtual pupil ... that is, to get in the shoes of someone who will take the course." The designer of Learning Objects must take the role of the student to understand better their needs. Participant 4 emphasizes: "we should behave with simplicity, humility, ability to change to learn from mistakes", which results in a constant process of evaluation and adjustment of the LO to build not only knowledge but ICT competencies as well.

Teachers in the study remain at a Level 1 (literacy) and Level 2 (collaboration), regarding Tomei's Taxonomy, which means they understand technology and have interacted in virtual learning environments. The design and development of LO can push them through the levels in a way that teachers can use technology as a powerful strategy for uncovering and exploring academic content [9]. This means that the use of technology in the classroom goes beyond a disconnected incorporation, and that indeed shows an instructional value to help students become lifelong learners. Even though the results provided could be seen as 
predictable, it can be deduced that the academic field on which the courses take place may have a powerful influence not only on the instructional design of the Learning Objects, but also on its implementation. Actually, authors and tutors' literacy on ICT and on pedagogical skills may influence noticeably the development of usable and reusable Learning Objects.

\section{CONCLUSIONS AND PROSPECTS FOR FURTHER RESEARCH}

The investigation allowed collecting the information, experiences, and perception from a group of individuals with different professional backgrounds, but all of them related to the field of education. In accordance with the applied instruments, the participants expressed acceptance of the quality indicators that were proposed for the evaluation of Learning Objects (see Tables 1, 2, and 3). It is important to point out that, although the study's sample is too small to generalize conclusions, the interpretation of the results contributes as a pilot- study in the subject of LO. Several suggestions stem from this research, on first instance to be applied in the Law Faculty where the study was conducted, but that can also help other educational institutions and teachers that are going through a similar process.

For the development or selection of Learning Objects, some guidelines should be kept in mind: first, it is important to consider the goals of instructional design and means that facilitate their dissemination and use. These LO must be designed focusing on the learner's context and the function they have to carry out within that context [20]; in other words, instructional designers should conceive them bearing in mind the objectives as well as the outcomes expected. Second, the collaboration of an interdisciplinary team experienced in virtual learning environments is also helpful for a better development and creation of LO. Working individually and independently, it is difficult to achieve consistency between what is expected as a product and the product itself. Third, it is also important that the Learning Objects be dynamic; this implies that they can be changed at any stage, from conception to execution.

All of the above should be part of a continuous LO evaluation process based on learners' needs and course objectives. Therefore, the feedback provided by students, teachers and computer programmers is an essential indicator for the development of Learning Objects and their compliance with the parameters established in the instructional design.

Additionally, and regardless of the discipline to teach or the platform to use, it is recommended that LOs include objectives, instructions, start and end time, contents, description of the activity, rubrics, and literature. Therefore, LO should potentiate ICT skills according to the same learning objective: obtaining new knowledge.

As for the quality of a learning object, findings suggest that it must be functional and contain new, valuable, and interesting content. Its evaluation should involve the purpose of instruction, the competencies to be developed and indicators that include elements for optimal LO and allow continuous feedback from students and tutors. Also, recognizing that the reuse of LO designed for the classroom is possible, this requires a definition of parameters and quality indicators in the process of adjustment and adaptation to the virtual environment.

During the process of updating and adapting course content to a virtual platform, the quality and effectiveness of LO can be challenged. At the same time, the problem of time constraints and lack of both human and economic resources is often faced, and teachers turn to the resources offered by the Internet. In the case of this study, the development of LO is still an important issue since it is necessary to identify components that can contribute to design more flexible Learning Objects than the ones already available. Actually, they should meet the open resources criteria to be truly and effectively reusable.

However, more research is needed to resolve questions such as: Could LO be standardized? If such standardization could be achieved, would it not affect their quality and 
originality? How much should students participate in evaluating Learning Objects? Finally, it is necessary to find repositories that are adaptable and address the needs of students.

LOs are dynamic; this implies that they are susceptible to change in any of their stages: from conception to execution. The LOs must be subject to continuous assessment based on the needs of the apprentice and the objectives of the course. Therefore, the feedback provided by students, teachers and programmers is an essential part of the development of an LO that meets the parameters established in the instructional design.

\section{REFERENCES (TRANSLATED AND TRANSLITERATED)}

[1] L. Alemánand M. G. Gómez-Zermeño,'Liderazgo Docente para la Enseñanza de la Innovación',Revista de Investigación Educativa, vol. 2, no. 4, pp. 2-7, 2012.(in Spanish)

[2] M. G. Gómez-Zermeño andL. Alemán, 'Temoa: An Open Educational Resources Portal to seek,investigate and inquire',Open Praxis, vol. 7, no. 3, pp. 211-226, 2015. (in English)

[3] Y. Góngora and O. L. Martínez, 'Del diseño instruccional al diseño de aprendizaje con aplicación de las tecnologías',Teoría de la Educación: Educación y Cultura en la Sociedad de la Información, vol.13,no.3, pp.342-360, 2012.(in Spanish)

[4] G. Kaplún, 'Aprender y enseñar en tiempos de Internet Formación profesional a distancia y nuevas tecnologías', Montevideo: CINTERFOR/OIT, 2005[Online]. Available: http://www.oitcinterfor.org/sites/default/files/file_publicacion/kaplun.pdf. (in Spanish)

[5] D. Churchill, 'Towards a useful classification of learning objects',Educational Technology Research and Development, vol. 5, no.55, pp. 479-497,2007. (in English)

[6] A.Olivar and A. Daza, 'Las tecnologías de la información y comunicación (TIC) y su impacto en la educación del siglo XXI' Negotium, vol. 3, no.7, pp. 21-46, 2007[Online]. Available: http://www.joseacontreras.net/admon/Competitividad/competitividadotrospfs/revsitanegotiumorgve/07_A rt02_LasTICImpactoEducacionSigloXXI.pdf (in Spanish)

[7] V. Štuikys and R.Damaševičius, 'Towards knowledge-based generative learning objects',Information technology and control, vol. 36, no. 2, 2015. (in English)

[8] A.Virtue, E. Dean andM.Matheson, 'Assessing Online Learning Objects: Student Evaluation of a Guide on the Side Interactive Learning Tutorial Designed by SRJC Libraries', Interdisciplinary Journal of ELearning and Learning Objects, vol. 10, pp. 93-105, 2014. (in English)

[9] L. A. Tomei,Taxonomy for the technology domain. Hershey, PA: Information Science Publishing, 2005. (in English)

[10] E. Parra, 'Propuesta de metodología de desarrollo de software para objetos virtuales de aprendizajeMESOVA',Revista Virtual Universidad Católica Del Norte, vol.1, no.34, pp.113-137, 2011, [Online]. Available: http://revistavirtual.ucn.edu.co/index.php/RevistaUCN/article/viewFile/332/636(in Spanish)

[11] M. Del Moral and D. Cernea, 'Diseñando Objetos de Aprendizaje como facilitadores de la construcción del conocimiento' (Vol. 19, p. 20). I Simposio Pluridisciplinar sobre Diseño, Evaluación y Descripción de Contenidos Educativos Reutilizables (SPDECE) Barcelona, 2005 [Online]. Available: http://www.uoc.edu/symposia/spdece05/pdf/ID16.pdf (in Spanish)

[12] L. Vargas, M.G. Gómez-Zermeño andR.Gómez-Zermeño. 'Desarrollo de habilidades cognitivas y tecnológicas con aprendizaje móvil', Revista de Investigación Educativa de la Escuela de Graduados en Educación, vol.3, no.6, pp. 30-39, 2013[Online]. Available: http://rieege.tecvirtual.mx/index.php/rieege/article/view/76(in Spanish)

[13] M. Prendes, F. Martínez and I. Gutiérrez, 'Producción de material didáctico: los objetos de aprendizaje'. Revista Iberoamericana de Educación a Distancia, vol. 11, no. 1, pp. 88-105, 2012[Online]. Available: http://ried.utpl.edu.ec/images/pdfs/volumen11/Martinez-Prendes.pdf(in Spanish)

[14] F. Ramírez, and A. Zwerg-Villegas, 'Research Methodology: More than a recipe'. AD-Minister, vol. 20, no. (enero-julio), pp. 91-111, 2012.[Online]. Available: http://publicaciones.eafit.edu.co/index.php/administer/article/view/1344/1215(in English)

[15] J. Valenzuela,and M. Flores, Fundamentos de Investigación educativa Vol. 2: El proceso de investigación educativa. Monterrey, México: Editorial Digital del Tecnológico de Monterrey, 2012.(in Spanish)

[16] M. Ardila-Rodríguez, 'Indicadores de calidad de las plataformas educativas digitales',Educación y educadores, vol.14, no. 1, pp.189-206, 2011.(in Spanish)

[17] L. Chiappe, 'Diseño instruccional: oficio, fase y proceso', Educación y Educadores, vol. 11,no.2, pp.229239,2008[Online].Available: 
http://web.b.ebscohost.com.ezproxy.unisabana.edu.co/ehost/pdfviewer/pdfviewer?sid=8cd95903-45c042a1-8cbc-(in Spanish)

[18] G. Astudillo, C. Sanz, andP. Willging, 'Repositorios de Objetos de Aprendizaje: un espacio de búsqueda centrado en lo educativo'. Presented at the VII Congreso de Tecnología en Educación y Educación en Tecnología, Universidad Nacional del Noroeste (Buenos Aires, Argentina): Red de Universidades con Carreras en Informática (RedUNCI). 2012. [Online]. Available: http://hdl.handle.net/10915/18494(in Spanish)

[19] J. Onrubia, 'Aprender y enseñar en entornos virtuales: actividad conjunta, ayuda pedagógica y construcción del conocimiento',RED Revista de Educación a Distancia, vol. 4, no. 2, pp. 1-16,2005. [Online]. Available: http://www.um.es/ead/red/M2/(in Spanish)

[20] M. Shaw, '(Contextual and mutated) learning objects in the context of design, learning and (re)use'.no 8, 2003[Online]. Available: http://www.shawmultimedia.com/edtech_oct_03.html (in English)

Text of the article was accepted by Editorial Team 01.12.2016

\title{
ВИБІР І ЯКІСТЬ ЦІЛЕЙ НАВЧАННЯ. ЧИ ВИЗНАЧЕНІ ВОНИ ПРАВИЛЬНО І ЧИ МОЖНА ЇХ ВИКОРИСТОВУВАТИ БАГАТОРАЗОВО?
}

\author{
Маргарита Марія Аяла Доваль \\ магістр гуманітарних наук з освітніх технологій \\ Монтеррейський технологічний інститут, Монтеррей, Мексика \\ ORCID ID 0000-0003-3015-4329 \\ margaritamariaayala@hotmail.com \\ Марсела Джорджина Гомес-Зерменьо \\ професор, $\mathrm{PhD}$ з освітніх інновацій \\ Монтеррейський технологічний інститут, Монтеррей, Мексика \\ ORCID ID 0000-0002-5427-2891 \\ marcela.gomez@itesm.mx
}

\begin{abstract}
Анотація. У даному пілотному дослідженні основна увага приділялася оцінці навчальних цілей поставлених для очної та онлайн форм навчання, для чого був запропонований набір показників якості, які ураховувалися проектними командами під час вибору навчальних матеріалів. Мета дослідження полягала в тому, щоб з'ясувати, чи достатньо відповідають поставлені цілі навчання на практиці і чи ї можна буде використовувати ще раз. У дослідженні брали участь обрані для цього викладачі, тьютори та фахівці комп'ютерники, які задіяні у програмах для студентів останніх курсів та для випускників Колумбійського університету. Для аналізу зібраних даних показники оцінки якості цілей навчання грунтувалися на трьох основних аспектах: ролі наставників (тьюторів) i їх попередній досвід, процесі проектування і оцінці мети навчання. У висновках встановлено, що стандартизація цілей навчання може бути важким процесом, для їх багаторазового використання вони повинні бути гнучкими, щоб їх можна було адаптувати до потреб учнів.
\end{abstract}

Ключові слова: цілі навчання; репозитарії; інформаційні та комунікаційні технології; показники; якість.

\section{ВЫБОР И КАЧЕСТВО ЦЕЛЕЙ ОБУЧЕНИЯ. ПРАВИЛЬНО ЛИ ОНИ ОПРЕДЕЛЕНЫ И МОЖНО ЛИ ИХ ИСПОЛЬЗОВАТЬ МНОГОКРАТНО?}

\author{
Маргарита Мария Аяла Доваль \\ магистр гуманитарных наук по образовательным технологиям \\ Монтеррейский технологический институт, Монтеррей, Мексика \\ ORCID ID 0000-0003-3015-4329 \\ margaritamariaayala@hotmail.com
}




\section{Марсела Джорджина Гомес-Зерменьо}

профессор, $\mathrm{PhD}$ по образовательным инновациям

Монтеррейский технологический институт, Монтеррей, Мексика

ORCID ID 0000-0002-5427-2891

marcela.gomez@itesm.mx

Аннотация. В данном пилотном исследовании основное внимание уделялось оценке учебных целей, поставленных для очной и онлайн форм обучения. Для этого был предложен набор показателей качества, который использовался проектными командами при выборе учебных материалов. Цель исследования состояла в том, чтобы выяснить, достаточно ли соответствуют поставленные цели обучения на практике и можно ли их будет использовать еще раз. В исследовании участвовали преподаватели, тьюторы и специалисты компьютерщики, которые задействованы в программах для студентов последних курсов и для выпускников Колумбийского университета. Для анализа собранных данных показатели оценки качества целей обучения основывались на трех основных аспектах: роли наставников (тьюторов) и их предыдущий опыт, процессе проектирования и оценке цели обучения. В выводах установлено, что стандартизация целей обучения может быть трудным процессом, однако для того, чтобы их можно было использовать многократно, цели обучения должны быть гибкими, чтобы их можно было адаптировать к потребностям учащихся.

Ключевые слова: цели обучения; репозитарии; информационные и коммуникационные технологии; показатели; качество. 